\title{
Zespół pęcherza nadreaktywnego - niedoszacowany problem chorych na cukrzycę
}

\author{
An overactive bladder - underestimated trouble of diabetic patients
}

\section{STRESZCZENIE}

Zespół pęcherza nadreaktywnego (ZPN) jest schorzeniem bardzo rozpowszechnionym w populacji ogólnej, charakteryzującym się wieloczynnikową i nie do końca poznaną etiologią. Jego objawy stwierdza się także $\mathrm{u}$ istotnego odsetka chorych na cukrzycę. Na obraz kliniczny ZPN składa się wiele symptomów, które znacząco pogarszają komfort życia chorego (tj. parcia naglące, częstomocz, nocturia, nietrzymanie moczu z parcia). Podstawę diagnostyki stanowi ukierunkowany powyższe objawy wywiad podmiotowy, a warunkiem rozpoznania tak zwanego idiopatycznego zespołu pęcherza nadreaktywnego jest wykluczenie innych czynników (anatomicznych, czynnościowych i metabolicznych), które mogą powodować podobne objawy kliniczne. U podłoża patogenetycznego ZPN leżą: nieprawidłowa budowa i funkcja nabłonka wyścielającego drogi moczowe (urotelium), zaburzenia unerwienia pęcherza moczowego i zaburzenia czynności mięśnia wypieracza pęcherza moczowego. Czynnikami wpływającymi na rozwój ZPN u chorych na cukrzycę są: hiperglikemia

Adres do korespondencji:

dr n. med. Marcin Życzkowski

Katedra Urologii w Zabrzu

Śląskiego Uniwersytetu Medycznego w Katowicach

ul. 3-Maja 13-15, 41-800 Zabrze

Tel.: +48 (32) 37044 54, faks: +48 (32) 3704453

e-mail: mzyczkowski@poczta.onet.pl

Diabetologia Kliniczna 2015, tom 4, 1, 13-21

DOI: $10.5603 /$ DK.2015.0003

Copyright (C) 2015 Via Medica

Nadesłano: 16.12.2014

Przyjęto do druku: 19.01.2015 i stymulowana nią poliuria, a także późne powikłania cukrzycy pod postacią mikroangiopatii i polineuropatii. Sposób terapii ZPN u chorych z cukrzycą nie odbiega od schematów przyjętych dla populacji ogólnej, choć podkreśla się rolę optymalizacji leczenia hipoglikemizującego. Niestety nawet długotrwałe stosowanie wielokierunkowej terapii (niefarmakologicznej, farmakologicznej czy zabiegowej) nie zapewnia pełnego wyleczenia ZPN, a jej efekt często sprowadza się jedynie do zmniejszenia nasilenia objawów klinicznych. (Diabet. Klin. 2015; 4, 1: 13-21)

Słowa kluczowe: zespół pęcherza nadreaktywnego, cukrzyca, późne powikłania cukrzycy

\section{ABSTRACT}

An overactive bladder (OAB) is a prevalent syndrom in general population with uncertain multifactorial aetiology. The features of $O A B$ are also present in significant percent of diabetics. The clinical picture of $O A B$ consists of troublesome clinical symptoms (urgency, frequency, nocturia, urge urinary incontinence). The precise medical history is the base of proper $O A B$ diagnosis and the exclusion of all known reasons for OAB (anatomical, functional and hormonal) is essential to confirm its idiopathic aetiology. The background of $O A B$ is formed by the disturbances of both structure and function of urothelium besides urinary bladder innervation and muscular dysfunction. In diabetics, the hyperglycaemia and secondary polyuria as well as 
the late diabetic complications (microangiopathy and neuropathy) are responsible for the OAB development. The mode of $O A B$ treatment in diabetics does not differ from these accepted for general population, although the role of optimal hypoglycaemic therapy is emphasied. Unfortunately, even long-term multidirectional therapy (non-pharmacological, pharmacological or invasive treatments) does not ensure successful cure and all its effects are limited to mitigation of clinical signs intensity. (Diabet. Klin. 2015; 4, 1: 13-21)

Key words: overactive bladder, diabetes, late diabetic complications

\section{Wstęp}

Cukrzyca jest chorobą o wysokiej zachorowalności i istotnym wpływie na jakość życia. Szacuje się, że choruje na nią ponad 366 mln ludzi na świecie, a liczba ta $w$ następnych latach będzie lawinowo wzrastała [1]. Jako ogólnoustrojowa choroba metaboliczna, w przebiegu której dochodzi do rozwoju przewlekłych powikłań makro- i mikronaczyniowych, a w efekcie końcowym - do uszkodzenia wielonarządowego, cukrzyca leży w kręgu zainteresowań nie tylko diabetologów, lecz także wielu innych specjalności lekarskich. Nierzadko z powikłaniami cukrzycy musi zmierzyć się również urolog. W 1976 roku Cai Frimodt-Møller wprowadził po raz pierwszy termin „cystopatia cukrzycowa” dla określenia towarzyszących cukrzycowej polinuropatii autonomicznej objawów ze strony pęcherza moczowego, obejmujących między innymi zwiększoną pojemność pęcherza moczowego i objętość zalegającego w nim po mikcji moczu [2]. Aktualnie ocenia się, że powikłania urologiczne, to jest: cukrzycowa dysfunkcja pęcherza moczowego, zaburzenia seksualne czy infekcje dróg moczowych, występują u ponad $50 \%$ chorych na cukrzycę [2].

Jednym ze schorzeń dolnych dróg moczowych, mogącym stanowić powikłanie cukrzycy, jest, należący do schorzeń czynnościowych pęcherza moczowego, zespół pęcherza nadreaktywnego (ZPN). Na jego obraz kliniczny składa się wiele objawów, które znacząco pogarszają komfort życia pacjenta. Ze względu na rosnącą zapadalność na cukrzycę szacuje się, że w przyszłości będzie wzrastała liczba chorych, u których wystąpi ZPN. Stanowi to impuls do prowadzenia dalszych badań nad etiopatogenezą i metodami leczenia tego schorzenia.

\section{Definicja ZPN}

Pierwszy opis objawów odpowiadających ZPN to lata 20. XIX wieku i doniesienia H. Younga oraz D. Daviesa [2]. Bazująca na wytycznych Internationale
Continence Society (ICS) z 2002 roku, aktualnie obowiązująca definicja tego zespołu to występowanie jednego lub więcej z triady objawów klinicznych: parcia naglące, częste oddawanie moczu w ciągu całej doby (ponad 8 mikcji w ciągu dnia i ponad 3 mikcje w ciągu nocy) oraz naglące nietrzymanie moczu [3-6]. Warunkiem rozpoznania tak zwanego idiopatycznego zespołu pęcherza nadreaktywnego jest wykluczenie innej, organicznej, czynnościowej lub metabolicznej przyczyny tych objawów. Identyczne objawy mogą bowiem występować wtórnie do wielu schorzeń o etiologii neurogennej (np. po udarach czy urazach ośrodkowego układu nerwowego, w chorobie Parkinsona) lub nieneurogennej (np. w przebiegu zakażenia dróg moczowych, przerostu gruczołu krokowego, kamicy lub nowotworu pęcherza moczowego, w efekcie stosowania leków moczopędnych, dekompensacji metabolicznej lub hormonalnej). W tych sytuacjach objawy ZPN mogą być skutkiem zarówno nadreaktywności wypieracza czy nadwrażliwości sensorycznej (sensory urgency), jak i ograniczonej podatności pęcherza moczowego lub poliurii [5].

\section{Epidemiologia ZPN}

Praktyka kliniczna wskazuje, że zaburzenia funkcji pęcherza moczowego występują często u chorych na cukrzycę. Niestety nie są znane dokładne dane epidemiologiczne dotyczące tego problemu. Wynika to między innymi z faktu nakładania się na cukrzycę objawów innych chorób współistniejących, szczególnie w populacji osób starszych. Klasycznym przykładem takiego wspólnego obrazu chorobowego jest współwystępowanie z cukrzycą rozrostu gruczołu krokowego czy zespołu pęcherza neurogennego. Równie ważną przyczyną niedoszacowania skali występowania ZPN jest wstyd pacjentów przed ujawnieniem choroby [7]. Praktyka codzienna potwierdza, że objawy ZPN, w tym głównie nietrzymanie moczu, to jedna z „chorób przeżywanych w skrytości”, która istotnie pogarsza jakość życia pacjentów, powodując często ich dobrowolne wycofanie się z życia społecznego [3, 8].

Zaburzenia czynności pęcherza moczowego występują aż u 25-87\% chorych na cukrzycę [10]. Zwykle rozwijają się one u pacjentów z długo trwającą i nie w pełni kontrolowaną chorobą, a częstość ich występowania koreluje głównie z czasem trwania cukrzycy i wiekiem chorych [10].

Przekrój objawów klinicznych ZPN i ich nasilenie są u chorych na cukrzycę bardzo różnorodne. Najczęstszym objawem, szczególnie wśród chorujących na cukrzycę kobiet, jest nietrzymanie moczu. W badaniu Lifford i wsp. [11] opartym na dużej grupie kobiet obserwowanych w ramach projektu Nurses' Health Study 
(NHS) stwierdzono znamiennie częstsze występowanie nietrzymania moczu wśród chorych na cukrzycę, a ryzyko tego objawu wzrastało wraz z czasem trwania cukrzycy (2-3-krotnie u osób z dłuższym od 5 lat wywiadem trwania cukrzycy). Obserwacje kliniczne wskazują, że istotnym czynnikiem ryzyka występowania nietrzymania moczu są także: starszy wiek, otyłość i ogólny zły stan zdrowia [12].

W opublikowanym w 2014 roku przez Karoli i wsp. [13] doniesieniu ZPN rozpoznano u 53\% badanych kobiet z cukrzycą typu 2 mających objawy ze strony dolnych dróg moczowych. Wyniki badań przeprowadzonych przez Lee i wsp. [14] porównujące 194 kobiet z cukrzycą typu 2 i grupę kontrolną 162 kobiet zdrowych wykazały, że u chorych na cukrzycę znamiennie częściej występowała nokturia, słaby strumień moczu, zmniejszone objętości wydalonego moczu i niższy maksymalny przepływ cewkowy. Kaplan i wsp. [15], analizując retrospektywnie wyniki badania urodynamicznego 182 chorych na cukrzycę, tylko u 1 osoby nie ujawnili patologii! U 55\% pacjentów były obecne cechy nadreaktywności wypieracza, u 10\% - arefleksji wypieracza, a u $23 \%$ - cechy zmniejszonej kurczliwości pęcherza moczowego. Po wykluczeniu osób mających objawy ze strony kręgosłupa krzyżowego zaburzenia aktywności wypieracza stwierdzono w sumie u $74 \%$ badanych [15]. W swojej obserwacji klinicznej Ho i wsp. [16] stwierdzili objawy pęcherza nadreaktywnego u 36,2\% pacjentów z cukrzycą. Przykłady doniesień epidemiologicznych można mnożyć, wszystkie one jednak wskazują na predylekcję chorych na cukrzycę, szczególnie typu 2, do współwystępowania objawów ZNP.

Zespół pęcherza nadreaktywnego nie jest zaburzeniem swoistym dla cukrzycy. Dane epidemiologiczne dowodzą, że jego objawy obserwuje się także w istotnym odsetku populacji ogólnej. Na przykład w badaniu EPIC, prowadzonym w populacji mieszkańców Niemiec, Wielkiej Brytanii, Włoch, Szwecji i Kanady, objawy ZPN występowały u niemal $12 \%$ spośród 19000 badanych [17]. Z kolei w amerykańskim badaniu NOBLE, obejmującym ponad 11000 osób, ZPN rozpoznano u 16\% ankietowanych mężczyzn i u 16,9\% kobiet [18]. Wśród chorych zgłaszających objawy typowe dla ZPN duży odsetek stanowią osoby prowadzące siedzący tryb życia, stosujące używki, pacjenci z depresją, zaburzeniami snu, mający zaparcia, kobiety otyłe i będące w okresie menopauzy [3].

\section{Objawy kliniczne ZPN}

Objawy pęcherza nadreaktywnego należą do tak zwanych objawów fazy napełniania pęcherza moczowego i są efektem nieprawidłowości dotyczących procesu rozkurczania lub/i skurczu wypieracza pęcherza moczowego $w$ trakcie wypełniania moczem.
Fizjologicznie mikcja jest procesem świadomym, a odczucie potrzeby oddania moczu występuje po wypełnieniu około 2/3 maksymalnej objętości pęcherza moczowego, która wynosi około 400-600 ml [19]. W przypadku ZPN skurcz wypieracza staje się niezależny od stopnia wypełnienia pęcherza moczowego i w ten sposób mikcja przestaje podlegać świadomej kontroli chorego [20].

Dlatego też klasycznymi objawami ZPN są: parcia naglące, częstomocz i nocturia. Może również wystąpić nietrzymanie moczu z parcia. Są to objawy dokuczliwe dla chorego, ograniczające jego aktywność życiową, a często również wpływające destabilizująco na jego psychikę [2].

Efektem zaburzeń spowodowanych cukrzycą może być zarówno niewydolność mięśnia wypieracza pęcherza moczowego, jak i jego nadreaktywność [20]. Przy czym badania wskazują, że objawy wynikające z zaburzeń w fazie napełniania pęcherza moczowego występują u chorych na cukrzycę w starszym wieku znacznie częściej niż te dotyczące fazy opróżniania [21]. Ponadto wykazano, że u mężczyzn chorujących na cukrzycę typu 2 z objawami ZPN znamiennie częściej współwystępują zaburzenia erekcji [23].

\section{Etiopatogeneza ZPN}

Przyczyny nadreaktywności pęcherza moczowego nie zostały do dziś w pełni poznane. Istnieje kilka hipotez dotyczących patofizjologii tych zaburzeń.

U podłoża zrozumienia patofizjologii ZNP leży złożony proces neurofizjologiczny, jakim jest mikcja. Składa się on z dwóch faz: fazy napełniania pęcherza moczowego i fazy opróżniania pęcherza moczowego, które wymagają koordynacji nerwowej. Wypełniający się moczem pęcherz moczowy wysyła sygnały nerwowe do znajdujących się w rdzeniu kręgowym i moście ośrodków mikcji. Włókna układu współczulnego prowadzą zwrotne impulsy do pęcherza moczowego rozluźniające jego mięśniówkę, tworząc zbiornik dla gromadzącego się moczu. Stale zwiększająca się częstość impulsów eferentnych z wypełnionego pęcherza moczowego zaczyna stymulować ośrodek mikcji i po przekroczeniu progu pobudzenia, gdy równocześnie zablokowane zostaną hamujące sygnały z kory mózgu (odpowiadające za świadomą kontrolę mikcji), drogą włókien przywspółczulnych indukuje skurcz wypieracza pęcherza moczowego. Zaburzenie któregokolwiek ogniwa prawidłowego odruchu mikcji może wywołać różne zaburzenia funkcji pęcherza moczowego $[2,19,20]$.

Wiedza na temat patofizjologii ZPN w cukrzycy w dużej mierze opiera się na wynikach badań przeprowadzonych na modelach zwierzęcych cukrzycy indukowanej streptozocyną, a więc modelu najbardziej 
zbliżonym do cukrzycy typu 1 u ludzi. Jest to duże ograniczenie metodologiczne, ponieważ dominujący odsetek chorych na świecie prezentuje typ 2, a nie 1 cukrzycy, w którym współistnieją często cechy zespołu metabolicznego, a nad niedoborem insuliny dominuje insulinooporność. Dlatego też w najnowszej literaturze podkreśla się konieczność kontynuowania badań dotyczących tego zagadnienia [2].

Dotychczas zebrane dane wskazują, że patofizjologia ZPN w cukrzycy jest złożona. Biorą w niej udział: zaburzenia dotyczące struktury i funkcji nabłonka wyścielającego drogi moczowe - urotelium, zaburzenia unerwienia pęcherza moczowego i zaburzenia czynności mięśnia wypieracza pęcherza moczowego [2, 23-27]. Uważa się, że są one przede wszystkim skutkiem swoistego dla cukrzycy stanu hiperglikemii i zwiększonej objętości moczu [2].

\section{Zaburzona struktura i funkcja urotelium}

Nabłonek dróg moczowych, tak zwane urotelium, dzięki swej specyficznej budowie i czynności jest istotnym czynnikiem warunkującym zachowanie lokalnej homeostazy i prawidłowej funkcji dolnych dróg moczowych $[20,23]$. Urotelium reguluje przepuszczalność, endocytozę i transport przez ścianę pęcherza moczowego. Posiada zdolność do rozciągania i kurczenia się, co ma ogromne znaczenie przy napełnianiu i opróżnianiu pęcherza moczowego. Pełni także funkcję sensoryczną i neuroendokrynną, będąc istotnym ogniwem w prawidłowym odruchu mikcji. Nabłonek dróg moczowych połączony z włóknami aferentnymi (tj. doprowadzającymi) i eferentnymi (tj. odprowadzającymi) układu nerwowego warunkuje zachowanie prawidłowego czucia pęcherzowego i odruchów związanych z aktem mikcji. Na poziomie molekularnym we włóknach nerwowych leżących bezpośrednio między komórkami urotelium znajdują się liczne receptory peptydowe (m.in. receptory purynergiczne, bradykininowe, nikotynowe, muskarynowe, alfa- i beta-adrenergiczne), a także receptory o charakterze kanałów jonowych, zwane receptorami waniloidowymi. Ich specyficzne wzajemne oddziaływanie za pomocą neuroprzekaźników, do których należą między innymi: adenozynotrójfosforan (ATP), bradykinina, acetylocholina i noradrenalina, warunkuje prawidłowy odruch mikcji. Receptory waniloidowe w warunkach fizjologicznych modulują rozciągliwość ściany pęcherza w reakcji na wypełnienie moczem. W warunkach patologicznych przy nadmiernej impulsacji odpowiadają za objawy nadreaktywności wypieracza [23].

Wyniki badań przeprowadzonych na modelach zwierzęcych cukrzycy wykazały zwiększoną masę komórek urotelium, ale równocześnie zmiany w ekspresji receptorów na ich powierzchni i zaburzone uwalnianie neurotransmiterów. Ocena histopatologiczna nabłonka dróg moczowych w mikroskopie elektronowym ujawniła złuszczanie się komórek warstwy powierzchownej urotelium już w 9. tygodniu od eksperymentalnego wywołania cukrzycy, wskazując tym samym na wczesne przełamanie funkcji bariery mocz/tkanki pęcherza moczowego [2]. Podobnie wcześnie (od 3. tygodnia rozwoju cukrzycy) ujawniono zwiększoną ekspresję enzymu szlaku poliolowego — reduktazy aldozy i czynnika wzrostu nerwów, a w okresie późniejszym także receptorów z rodziny waniloidowych (warunkujących mechanowrażliwość) oraz receptorów purynergicznych i muskarynowych (włączonych w auto- i paraktynny szlak sygnałowy). Te obserwacje dowodzą, że występujące w cukrzycy zmiany strukturalne i czynnościowe urotelium mogą modulować aktywność znajdujących się w ich okolicy zakończeń nerwów aferentnych [2].

Urotelium pełni także funkcję barierową dla substancji zawartych w moczu. Uszkodzenie nabłonka poprzez czynniki miejscowe (np. glikozurię) lub/i ogólnoustrojowe powoduje przenikanie szkodliwych metabolitów z moczu w głąb tkanek pęcherza moczowego, co skutkuje uszkodzeniem ich struktury oraz funkcji, i ostatecznie prowadzi do wystąpienia objawów ZPN. Uszkodzenie barierowej funkcji urotelium wpływa również na zmiany ekspresji czynników antyproliferacyjnych, co powoduje zahamowanie odnowy nabłonka i nasileniem objawów choroby.

Funkcja antyadhezyjna urotelium, którą wykazuje ono dzięki powierzchniowej warstwie glikozoaminoglikanów, ma decydujące znaczenie w miejscowej ochronie dróg moczowych przeciwko inwazji drobnoustrojów. W przypadku wystąpienia infekcji w obrębie dróg moczowych dochodzi do uruchomienia kaskady czynników pro- i przeciwzapalnych, co skutkuje uszkodzeniem ciągłości urotelium. Taki mechanizm lokalnego uszkadzania urotelium stwierdzono również w cukrzycy [20, 28].

\section{Zaburzenia unerwienia pęcherza moczowego}

Wyniki licznych badań wykazały związek przyczynowy między dysfunkcją pęcherza moczowego a obwodową polineuropatią cukrzycową $[2,27]$. Obserwacje szczurów Goto-Kakizaki z cukrzycą (przypominającą przebiegiem typ 2 cukrzycy u ludzi) ujawniły dysfunkcję czuciową pęcherza moczowego manifestującą się zmniejszeniem szybkości przewodzenia we włóknach aferentnych i zwiększeniem pojemności pęcherza moczowego. Uważa się, że procesy te są efektem zaburzonego w cukrzycy metabolizmu glukozy skutkujących patologicznymi procesami glikacji oraz niekorzystnym gromadzeniem sorbitolu i fruktozy w komórkach nerwowych [20]. Hipotetycznymi czynnikami sprawczymi 
polineuropatii są również: niedotlenienie, produkcja wolnych rodników tlenowych, a także zaburzenia transportu aksonalnego (głównie czynnika wzrostu nerwów - NGF, nerve growth factor), skutkujące degeneracją aksonów i ich odcinkową demielinizacją [26]. Stwierdzenie obniżonego stężenia NGF, zarówno w tkankach pęcherza moczowego, jak i w splotach nerwowych odcinka L6-S1 kręgosłupa, może wskazywać na zaburzenia trofiki nerwów obwodowych jako przyczyny obserwowanej neurodegeneracji [26]. Inną koncepcję zaproponowali Yamaguchi i wsp. [27], sugerując patogenetyczne znaczenie w rozwoju ZPN uszkodzenia centralnego układu nerwowego $w$ efekcie mnogich zawałów będących skutkiem cukrzycowej waskulopatii.

\section{Zaburzenia funkcji mięśnia wypieracza pęcherza moczowego}

Ważnym mechanizmem ZPN jest nadreaktywność wypieracza pęcherza moczowego. Uważa się, że primum movens tej patologii może być, występujące wskutek towarzyszącej cukrzycy poliurii, zwiększenie ciśnienia wewnątrzpęcherzowego, które wywołuje kompensacyjny przerost mięśniówki pęcherza i częściowe odnerwienie włókien mięśniowych [2]. To z kolei skutkuje licznymi zaburzeniami czynnościowymi we włóknach mięśniowych, czyli zwiększoną wrażliwością receptorów cholinergicznych (muskarynowych) i zwiększoną ekspresją receptorów purynergicznych P2 $\mathrm{X}_{1}$, a także zmianami w komunikacji międzykomórkowej. Wyniki badań przeprowadzonych na modelach zwierzęcych sugerują, że stymulatorem spontanicznie nasilonej aktywności miocytów mogą być komórki śródmiąższowe pęcherza moczowego. Nawet miejscowe zakłócenia czynności mięśniówki pęcherza stymulują aktywność aferentnych włókien nerwowych, co skutkuje powstaniem odczucia nagłości mikcji i nadaktywności wypieracza [24]. Obserwacje kliniczne, a także badania przeprowadzone na modelach zwierzęcych potwierdzają występowanie zwiększonej grubości mięśniówki pęcherza u chorych na cukrzycę [26, 29].

Uważa się, że występująca w stanach hiperglikemii, a stymulowana glikozurią, zwiększona diureza powoduje zwiększenie ciśnienia śródpęcherzowego i przewlekłe rozciągnięcie ścian pęcherza moczowego, co skutkuje przerostem mięśniówki pęcherza [2]. W badaniach przeprowadzonych na zwierzętach, u których wywołano cukrzycę podaniem streptozocyny, stwierdzono we wczesnym okresie obserwacji (1-2 tygodni) indukowany diurezą przerost mięśni gładkich wypieracza. Wykazano także wzrost gęstości receptorów muskarynowych, zwiększone uwalnianie neurotrasmiterów i zaburzenie funkcjonowania pomp jonowych, takich jak $\mathrm{Na}^{+} / \mathrm{K}^{+}$-ATP-aza czy Ca ${ }^{2+}$-ATP-aza [2].
Badania wskazują, że u chorych na cukrzycę czynnikiem wpływającym negatywnie na funkcjonowanie mięśnia wypieracza pęcherza moczowego na poziomie molekularnym jest także zwiększony stres oksydacyjny. Stymuluje on apoptozę włókien mięśniowych i ingeruje w aktywność neurotrofin, takich jak NGF, nasilając neurodegenerację $[2,30]$.

Sugeruje się również, że powikłania makroangiopatyczne cukrzycy, pod postacią nasilonej miażdżycy, mogą powodować przewlekłe niedokrwienie pęcherza moczowego i tą drogą zaburzać jego strukturę i czynność [13].

\section{Czynniki ryzyka ZPN w cukrzycy}

Wyniki badań przeprowadzonych w populacji ogólnej wskazują, że istotnymi czynnikami ryzyka wystąpienia ZPN są insulinooporność i obecność cech zespołu metabolicznego [31, 32]. Także towarzysząca cukrzycy hiperglikemia stanowi czynnik ryzyka wystąpienia ZPN. W badaniu Chiu i wsp. [33] stwierdzono, że wysokie stężenie hemoglobiny glikowanej może być niezależnym predyktorem pojawienia się objawów nadreaktywności pęcherza. Liczne obserwacje kliniczne potwierdzają, że częstość występowania objawów ZPN wzrasta wraz z czasem trwania cukrzycy [11].

W grupie chorujących na cukrzycę, szczególnie typu 2, częściej niż w ogólnej populacji występują takie czynniki ryzyka ZPN, jak otyłość, a wraz z nią nieprawidłowa dieta i mała aktywność fizyczna [12, 34]. Ważnymi czynnikami ryzyka w tej grupie osób są także: starszy wiek i nawracające infekcje dróg moczowych [35, 36]. Niebagatelne znaczenie mają również wynikające z polineuropatii autonomicznej zaburzenia funkcji motorycznej układu pokarmowego, powodujące zaparcia czy zaburzenia funkcji czuciowej odbytnicy. Wpływają one negatywnie na funkcjonowanie układu moczowego poprzez stałe zwiększenie ciśnienia w jamie brzusznej i zaburzenie funkcji mięśniówki dna miednicy. Obserwacje kliniczne wskazują, że ważnymi wskaźnikami ryzyka wystąpienia ZPN jest obecność innych późnych powikłań cukrzycy (szczególnie neuropatii i nefropatii) oraz współwystępowanie cech zespołu metabolicznego [13]. W badaniu Kebapci i wsp. [37] czynnikami prognostycznymi wystąpienia patologii pęcherza moczowego były w grupie chorych na cukrzycę typu 2: czas trwania choroby i jej złe wyrównanie, wiek, występowanie cech polineuropatii autonomicznej w zakresie układu sercowo-naczyniowego oraz przewodu pokarmowego i mikroalbuminuria.

\section{Diagnostyka ZPN}

Zarówno praktyka kliniczna, jak i dane epidemiologiczne z piśmiennictwa wskazują, że problem występo- 
wania zespołu pęcherza nadreaktywnego w populacji osób z cukrzycą jest niedoszacowany.

U pacjentów chorujących przez wiele lat na cukrzycę zwykle obecnych jest wiele schorzeń współistniejących i są oni leczeni przez lekarzy różnych specjalności. W tle różnorodnych objawów klinicznych, choćby związanych z chorobami układu sercowo-naczyniowego czy narządu wzroku, objawy dotyczące dolnych dróg moczowych mogą być przez nich bagatelizowane lub wstydliwe i dlatego mogą ich nie zgłaszać lekarzom. Zespół objawów może być także mylnie interpretowany zarówno przez chorego, jak i lekarza, jako skutek nawrotowych infekcji w drogach moczowych i być niepotrzebnie leczony seriami antybiotyków. Pominięcie w diagnostyce różnicowej ZPN skutkuje progresją objawów w czasie, późno postawioną diagnozą i w efekcie - późną (jeśli w ogóle podjętą) właściwą terapią.

W tym aspekcie wskazane jest rutynowe przeprowadzanie z chorym na cukrzycę dokładnego wywiadu lekarskiego ukierunkowanego na objawy ZPN. Należy mieć świadomość, że jest to najprostsze, najtańsze, a zarazem podstawowe narzędzie diagnostyczne w ZPN. Zwykle dopiero po podjęciu trafnego podejrzenia występowania tego zespołu rozpoczyna się właściwie ukierunkowany proces diagnostyczno-terapeutyczny [6].

Jak wspomniano, warunkiem rozpoznania ZPN jest wykluczenie innych czynników, które mogą powodować podobne objawy kliniczne. Dlatego też tak istotne jest równoczesne zebranie dokładnego wywiadu w kierunku schorzeń współistniejących i stosowanych przez chorego leków, a także przeprowadzenie wielu badań dodatkowych [26].

\section{Leczenie ZPN}

Sposób leczenia ZPN u chorych na cukrzycę nie odbiega od schematów przyjętych dla ogólnej populacji, choć podkreśla się znaczenie optymalizacji terapii hipoglikemizującej [26]. Istnieją zachęcające doniesienia oparte na wynikach badań przeprowadzonych na modelach zwierzęcych cukrzycy typu 1, że długotrwała efektywna insulinoterapia może odwrócić większość objawów ZPN [2]. Są to jednak obserwacje wymagające dalszych badań klinicznych.

Leczenie ZPN ma na celu poprawę jakości życia pacjenta, spowolnienie postępu choroby i uniknięcie powikłań ze strony układu moczowego [38-41]. Jest to proces długotrwały i złożony, a dla chorego, niestety, ani łatwy, ani w każdym przypadku skuteczny. Dlatego też konieczne jest uprzedzenie pacjenta o powyższym fakcie i przedstawienie mu dokładnego planu leczenia urologicznego.
Ze względu na złożone, i nie do końca jasne, czynniki patogenetyczne prowadzące do wystąpienia ZPN jego leczenie jest wielokierunkowe $[20,26,41]$.

Terapię pierwszego rzutu powinna stanowić zmiana stylu życia chorych. Zmniejszenie masy ciała poprawia funkcję mięśniówki dna miednicy małej i zmniejsza ryzyko wysiłkowego nietrzymania moczu [24, 42]. Właściwa dieta, ograniczenie używek i zmiana ilości, jakości i pory przyjmowanych płynów zmniejszają nasilenie objawów klinicznych [34].

Kolejnym elementem leczenia ZPN jest zastosowanie terapii fizykalnej, a więc ćwiczeń fizycznych mających na celu wypracowanie odruchów prawidłowej mikcji i wzmocnienie mięśni dna miednicy, co może w efekcie znacznie zredukować występujące w ZPN objawy.

W przypadku znacznego zaawansowania objawów ZPN konieczne jest wdrożenie farmakoterapii. Podjęcie decyzji o jej rozpoczęciu zawsze wymaga ustalenia, które objawy dominują u chorego - czy te związane z fazą gromadzenia moczu, czy te związane z mikcją.

W leczeniu ZPN wykorzystuje się wiele grup leków ordynowanych według indywidualnych wskazań [39-41].

Główną grupą leków stosowaną od wielu lat w ZPN są preparaty antymuskarynowe. Ich mechanizm działania polega na blokowaniu wiązania acetylocholiny z receptorami M2 i M3 w mięśniówce wypieracza pęcherza moczowego. Hamują one tą drogą niepożądane skurcze tego mięśnia. Co ważne, leki antymuskarynowe powodują zablokowanie receptorów muskarynowych jedynie w fazie napełniania pęcherza moczowego, nie upośledzają zatem kurczliwości mięśniówki pęcherza moczowego w fazie mikcji. Dostępnych jest wiele leków z tej grupy, na przykład: oksybutynina, tolterodyna, propiweryna, trospium i solifenacyna. Istotnym klinicznie ograniczeniem zastosowania preparatów antymuskarynowych są ich objawy niepożądane, a wśród nich głównie: suchość w jamie ustnej, zaburzenia widzenia, senność, zaburzenia poznawcze i zaparcia. Należy także pamiętać, że podstawowym przeciwskazaniem do ich stosowania jest jaskra z wąskim kątem przesączania. Unikalnym lekiem antymuskarynowym jest chlorek trospium, który ma działanie obwodowe i zmniejszoną penetrację do ośrodkowego układu nerwowego, co skutkuje zmniejszeniem częstości występowania niektórych objawów niepożądanych. Co ważne, lek ten nie jest metabolizowany przez enzymy grupy cytochromu P450. Ma to szczególnie istotne znaczenie u chorych leczonych doustnymi lekami hipoglikemizującymi, bo ogranicza występowanie interakcji międzylekowych.

Stale prowadzi się badania nad nowymi lekami mogącymi znaleźć zastosowanie w efektywnym leczeniu ZPN [43-45]. Wyniki badań przeprowadzonych 
na zwierzętach dowiodły pozytywnego wpływu inhibitorów TNF- $\alpha$ na dysfunkcję pęcherza moczowego w cukrzycy [28]. Obiecujące wyniki przyniosło badanie prowadzone na modelu zwierząt chorych na cukrzycę, w którym oceniano efekt terapeutyczny loperamidu działającego na receptory $\mu$ powodujące rozluźnienie mięśniówki pęcherza. Wyniki randomizowanego badania z użyciem leku działającego na ATP-wrażliwy kanał potasowy - nikorandilu wykazały jego skuteczność w zmniejszaniu parć i częstotliwości mikcji. Obiecujące wyniki dotyczące redukcji objawów ZPN przyniosły badania analogu receptora dla witaminy $D$ - elocalcitriolu. Obserwacje kliniczne zastosowania miejscowego preparatów estrogenowych u kobiet w okresie pomenopauzalnym wskazują na ich pozytywny wpływ na zmniejszenie parć naglących i częstomoczu. Do praktyki klinicznej wprowadzono również mirabegron - agonistę receptorów $\beta 3$-adrenergicznych, powodujących rozkurcz mięśniówki pęcherza moczowego. W przyszłości zastosowanie w terapii ZPN mogą znaleźć także leki działające na ośrodkowy układ nerwowy, które wpływają hamująco na odruch mikcji drogą stymulacji receptorów dopaminergicznych D1. Do takich wniosków prowadzą obserwacje pacjentów leczonych z powodu choroby Parkinsona, u których wykazano równoczesną redukcję objawów ZPN. Przedmiotem badań klinicznych są także leki miejscowo porażające włókna nerwowe w mięśniówce pęcherza moczowego. Takie działanie ma rosiniferatoksyna, powodująca tą drogą zmniejszenie objawów nadreaktywności wypieracza. Podobnym mechanizmem działania charakteryzuje się także, znajdująca powszechne zastosowanie w medycynie, toksyna botulinowa.

Leczenie inwazyjne ma ograniczone zastosowanie w leczeniu ZPN, chociaż uznaną metodą jest elektrostymulacja nerwów krzyżowych (SNM, sacral neuromodulation) [46]. Polega ona na wszczepieniu w pobliże nerwów krzyżowych na poziomie S3-S4 elektrody połączonej ze stymulatorem. Stymulacja taka powoduje wzrost napięcia zwieracza cewki moczowej, przy równoczesnym obniżeniu progu reaktywności ścian pęcherza moczowego. W badaniu Danielsa i wsp. [47] przy użyciu tej techniki z powodzeniem zredukowano nietrzymanie moczu z parcia u 69,2\% chorych, a parcia naglącego u 85,7\% pacjentów.

Opisywane w piśmiennictwie przypadki leczenia chirurgicznego ZPN (np. cystoplastyka zwiększająca pojemność pęcherza moczowego) nie znalazły powszechniejszego zastosowania w praktyce klinicznej [48].

W łagodzeniu objawów ZPN znajdują zastosowanie psychoterapia, biofeedback, leki przeciwdepresyjne, estrogeny, leki wpływające na układ adrenergiczny (doksazosyna) czy antagoniści wapnia (nifedypina). U części chorych korzystne efekty przynoszą dopęcherzowe wlewki glikozaminoglikanów [49-51].

Postęp nauki rozbudza nowe nadzieje na znalezienie efektywnej metody leczenia ZPN, a wśród nich jest na przykład transplantacja do ścian pęcherza moczowego komórek hodowli włókien mięśniowych czy komórek macierzystych [2, 52].

\section{Rokowanie}

Leczenie jest procesem wieloetapowym i rozłożonym w czasie, a z tego względu odbieranym często przez chorych jako mało efektywne. Wymaga ono od lekarza indywidualizacji przyjętego schematu postępowania, a od pacjenta zaufania i zaangażowania w proces terapeutyczny. W wielu przypadkach mimo wielokierunkowej terapii objawy ZPN ulegają jedynie niewielkiemu zmniejszeniu, a nie zupełnemu wycofaniu. Brak szybkiego efektu terapii, a także towarzyszące jej działania uboczne (np. suchość w ustach, zaparcia, bóle głowy) powodują, że część chorych rezygnuje z leczenia.

Mimo wielu możliwości terapii ZPN leczenie tego schorzenia u chorych na cukrzycę daje zwykle gorsze wyniki niż te osiągane w populacji ogólnej [30]. Być może powodem tego jest współwystępowanie u pacjentów z cukrzycą innych poważnych chorób, bowiem wyniki badań wskazują na ich wysoką motywację i wytrwałość w realizacji proponowanego schematu terapii $[53,54]$.

\section{Wnioski}

1. Częstość występowania ZPN u chorych na cukrzycę jest niedoszacowana między innymi ze względu na nakładanie się objawów innych chorób układu moczowego.

2. Patofizjologia tego zespołu jest złożona i uwarunkowana współwystępującymi zaburzeniami funkcji urotelium, mięśniówki i unerwienia pęcherza moczowego.

3. Możliwości terapeutyczne, takie jak: optymalizacja leczenia hipoglikemizującego połączona ze zmianą stylu życia, leczeniem behawioralnym, farmakoterapią oraz leczeniem inwazyjnym, pozwalają u części pacjentów na spowolnienie postępu choroby i zmniejszenie nasilenia objawów klinicznych, a dzięki temu na poprawę ich komfortu życia.

\section{Oświadczenie o konflikcie interesów}

Autorzy nie zgłaszają konfliktu interesów. 


\section{PIŚMIENNICTWO}

1. International Diabetes Federation. IDF diabetes atlas. Wyd. 5. International Diabetes Federation, Bruksela, Belgia (http://www. idf.org/diabetesatlas).

2. Liu G., Daneshgari F. Diabetic bladder dysfunction. Chin. Med. J. (Engl). 2014; 127: 1357-1364.

3. Wroński S., Radziszewski P., Lewczak D. Pęcherz nadreaktywny i naglące nietrzymanie moczu: choroba jednostki czy choroba społeczeństwa. Etiologia i leczenie. Przegl. Urol. 2010; 5 (63) (http://www.przeglad-urologiczny.pl/artykul.php?2039).

4. Abrams P., Cordozo L., Fall M. i wsp. The standarisation of terminology of lower urinary tract function: report from the Standardisation Sub-committee of the Internationale Continence Society. Neurourol. Urodyn. 2002; 21: 167-178.

5. Blaivas J.G. Overactive bladder and the definition of urgency. Neurourol. Urodyn. 2007; 26: 757-758.

6. Homma Y. OAB symptoms: assessment and discriminator for etiopathology. Curr. Opin. Urol. 2014; 24:345-351.

7. Brown J.S. Urinary incontinence: an important and underrecognized complication of type 2 diabetes mellitus. J. Am. Geriatr. Soc. 2005; 53: 2028-2029.

8. McDowell B.J., Engberg S.J., Rodriguez E., Engberg R., Sereika S. Characteristics of urinary incontinence in homebound older adults. J. Am. Geriatr. Soc. 1996, 44: 963-968.

9. Shaw C., Tansey R., Jackson C., Hyde C., Allan R. Barriers to help seeking in people with urinary symptoms. Fam. Pract. 2001; 18: 48-52.

10. Frimodt-Moller C. Diabetic cystopathy: epidemiology and related disorders. Ann. Int. Med. 1980; 92: 318-321.

11. Lifford K.L., Curhan G.C., Hu F.B., Barbieri R.L., Grodstein F. Type 2 diabetes mellitus and risk of developing urinary incontinence. J. Am. Geriatr. Soc. 2005; 53: 1851-1857.

12. Phelan S., Kanaya A.M., Subak L.L. i wsp. Action for Health in Diabetes (Look AHEAD) Research Group. Prevalence and risk factors for urinary incontinence in overweight and obese diabetic women: Action for health in diabetes (look ahead) study. Diabetes Care 2009; 32: 1391-1397.

13. Karoli R., Bhat S., Fatima J., Priya S. A study of bladder dysfunction in women with type 2 diabetes mellitus. Indian J. Endocrinol. Metab. 2014; 18: 552-557.

14. Lee W.C., Wu H.P., Tai T.Y., Liu S.P., Chen J., Yu H.J. Effects of diabetes on female voiding behavior. J. Urol. 2004; 172: 989-992.

15. Kaplan S.A., Te A.E., Blaivas J.G. Urodynamic findings in patients with diabetic cystopathy. J. Urol. 1995;153, 342-344.

16. Ho C.H., Tai H.C., Yu H.J. Urodynamic findings in diabetic female patients with and without overactive bladder symptoms. Neurourol. Urodyn. 2010; 29: 424-427.

17. Irwin D.E., Abrams P., Milsom I., Kopp Z., Reilly K.; EPIC Study Group. Understanding the elements of overactive bladder: questions raised by the EPIC study. BJU Int. 2008; 101: 1381-1387.

18. Stewart W.F., Van Rooyjen J.B., Cundiff G.W. i wsp. Prevalence and burden of overactive bladder in United States. World J. Urol. 2003; 20: 327-336

19. http://www.urology-textbook.com/bladder-function.html.

20. Golbidi S., Laher I. Bladder dysfunction in diabetes mellitus. Front. Pharmacol. 2010; 1: 136.

21. Starer P., Libow L. Cystometric evaluation of bladder dysfunction on elderly diabetic patients. Arch. Intern. Med. 1990; 150: 810-813.

22. Liu R.T., Chung M.S., Chuang Y.C. i wsp. The presence of overactive bladder wet increased the risk and severity of erectile dysfunction in men with type 2 diabetes. J. Sex Med. 2012; 9: 1913-1922.

23. Apodaca G. The uroepithelium: not just a passive barrier. Traffic 2004; 5: 117-128.

24. Yoshida M., Masunaga K., Nagata T. i wsp. The forefront for novel therapeutic agents based on the pathophysiology of lower urinary tract dysfunction: pathophysiology and pharmacotherapy of overactive bladder. J. Pharmacol. Sci. 2010; 112: 128-134.

25. Steers W.D. Pathophysiology of overactive bladder and urge urinary incontinence. Rev. Urol. 2002; 4 (supl. 4): S7-S18.
26. Gomez C.S., Kanagarajah P., Gousse A.E. Bladder dysfunction in patients with diabetes. Curr. Urol. Rep. 2011; 12: 419-426.

27. Yamaguchi C., Sakakibara R., Uchiyama T. i wsp. Overactive bladder in diabetes: a peripheral or central mechanism? Neurourol. Urodyn. 2007; 26: 807-813.

28. Birder L.A., de Groat W.C. Mechanisms of disease: involvement of the urothelium in bladder dysfunction. Nat. Clin. Pract. Urol. 2007; 4: 46-54.

29. Uzun H., Ogullar S., Sahin S.B. i wsp. Increased bladder wall thickness in diabetic and nondiabetic women with overactive bladder. Int. Neurourol. J. 2013; 17: 67-72.

30. Beshay E., Carrier S. Oxidative stress plays a role in diabetes induced bladder dysfunction in a rat model. Urology 2004; 64: 1062-1067.

31. Uzun H., Yilmaz A., Kemik A., Zorba O.U., Kalkan M. Association of insulin resistance with overactive bladder in female patients. Int. Neurourol. J. 2012; 16: 181-186.

32. Uzun H., Zorba O.Ü. Metabolic syndrome in female patients with overactive bladder. Urology 2012; 79: 72-75.

33. Chiu A.F., Huang M.H., Wang C.C. i wsp. Higher glycosylated hemoglobin levels increase the risk of overactive bladder syndrome in patients with type 2 diabetes mellitus. Int. J. Urol. 2012; 19: 995-1001.

34. McGrother C.W., Donaldson M.M., Thompson J., Wagg A., Tincello D.G., Manktelow B.N. Etiology of overactive bladder: a diet and lifestyle model for diabetes and obesity in older women. Neurourol. Urodyn. 2012; 31: 487-495.

35. Lin T.L., Chen G.D., Chen Y.C. i wsp. Aging and recurrent urinary tract infections are associated with bladder dysfunction in type 2 diabetes. Taiwan J. Obstet. Gynecol. 2012; 51: 381-386.

36. Liu R.T., Chung M.S., Lee W.C. i wsp. Prevalence of overactive bladder and associated risk factors in 1359 patients with type 2 diabetes. Urology 2011; 78: 1040-1045.

37. Kebapci N., Yenilmez A., Efe B. i wsp. Bladder dysfunction in type 2 diabetic patients. Neurourol. Urodyn. 2007; 26: 814-819.

38. Bartley J.M., Blum E.S., Sirls L.T., Peters K.M. Understanding clinic options for overactive bladder. Curr. Urol. Rep. 2013; 14: 541-548.

39. Jayarajan J., Radomski S.B. Pharmacotherapy of overactive bladder in adults: a review of efficacy, tolerability, and quality of life. Res. Rep. Urol. 2013; 6: 1-16.

40. Hanna-Mitchell A.T., Kashyap M., Chan W.V. i wsp. Pathophysiology of idiopathic overactive bladder and the success of treatment: a systematic review from ICI-RS 2013. Neurourol. Urodyn. 2014; 33: 611-617.

41. Maman K., Aballea S., Nazir J. i wsp. Comparative efficacy and safety of medical treatments for the management of overactive bladder: a systematic literature review and mixed treatment comparison. Eur. Urol. 2014; 65: 755-765.

42. Burgio K.L. Update on behavioral and physical therapies for incontinence and overactive bladder: the role of pelvic floor muscle training. Curr. Urol. Rep. 2013; 14: 457-464.

43. Robinson D., Giarenis I., Cardozo L. New developments in the medical management of overactive bladder. Maturitas 2013; 76: 225-229.

44. Wang Z., Cheng Z., Cristofaro V. i wsp. Inhibition of TNF-alfa improves the bladder dysfunction that is associated with type 2 diabetes. Diabetes 2012; 61: 2134-2145.

45. Lee L.M., Lin C.S., Chung H.H., Lin K.C., Cheng J.T. Urinary bladder relaxation through activation of opioid micro-receptors induced by loperamide is increased in diabetic rats. Exp. Clin. Endocrinol. Diabetes 2012; 120: 323-328.

46. Bartley J., Gilleran J., Peters K. Neuromodulation for overactive bladder. Nat. Rev. Urol. 2013; 10: 513-521.

47. Daniels D.H., Powell C.R., Braasch M.R., Kreder K.J. Sacral neuromodulation in diabetic patients: success and complications in the treatment of voiding dysfunction. Neurourol. Urodyn. 2010; 29: 578-581.

48. Veeratterapillay R., Thorpe A.C., Harding C. Augmentation cystoplasty: Contemporary indications, techniques and complications. Indian J. Urol. 2013; 29: 322-327. 
49. Dannecker C., Wolf V., Raab R. i wsp. EMG-biofeedback assisted pelvic floor muscle training is an effective therapy of stress urinary or mixed incontinence: a 7-year experience with 390 patients. Arch. Gynecol. Obstet. 2005; 273: 93-97.

50. Cui Y., Wang L., Liu L., Zeng F., Niu J., Qi L., Chen H. Botulinum toxin-A injections for idiopathic overactive bladder: a systematic review and meta-analysis. Urol. Int. 2013; 91: 429-438.

51. Iacovelli V., Topazio L., Gaziev G., Bove P., Vespasiani G., Finazzi Agrò E. Intravesical glycosaminoglycans in the management of chronic cystitis. Minerva Urol. Nefrol. 2013; 65: 249-262.
52. Song M., Heo J., Chun J.Y. i wsp. The paracrine effects of mesenchymal stem cells stimulate the regeneration capacity of endogenous stem cells in the repair of a bladder-outlet-obstruction-induced overactive bladder. Stem. Cells Dev. 2014; 23: 654-663.

53. Schneider T., Marschall-Kehrel D., Hanisch J.U., Michel M.C. Does concomitant diabetes affect treatment responses in overactive bladder patients? Int. J. Clin. Pract. 2013; 67: 1138-1143.

54. Johnston S., Janning S.W., Haas G.P. i wsp. Comparative persistence and adherence to overactive bladder medications in patients with and without diabetes. Int. J. Clin. Pract. 2012; 66: 1042-1051. 